\title{
KSZTAŁCENIE KANDYDATÓW NA OFICERÓW WOJSK LĄDOWYCH RP W ZAKRESIE KOMPETENCJI PRZYWÓDCZYCH
}

Z a ry s treś c i: Artykuł przedstawia wyniki autorskich badań prowadzonych na Wydziale Zarządzania Wyższej Szkoły Oficerskiej Wojsk Lądowych im. generała Tadeusza Kościuszki w zakresie projektowania nowoczesnych programów kształcenia podchorążych (kandydatów na oficerów) na kierunku Zarządzanie. Badania były zorientowane na doskonalenie kompetencji dowódczych (przywódczych) w trakcie studiów oraz ocenie ich przydatności na pierwszym i kolejnych stanowiskach służbowych (oficerskich) w jednostkach wojskowych.

S ło w a klu c z o w e: przywództwo; programy kształcenia; szkolnictwo wojskowe; kandydaci na żołnierzy zawodowych

Klasyfikacja JEL: M51; M53

\section{WSTĘP}

Współczesne organizacje, działając w trudno przewidywalnym środowisku politycznym, ekonomicznym, militarnym czy kulturowym, mają często problem z wykreowaniem (ujawnieniem się) ,prawdziwych lide-

* Adres do korespondencji: Andrzej Michaluk, Wyższa Szkoła Oficerska Wojsk Lądowych im. generała Tadeusza Kościuszki we Wrocławiu, Wydział Zarządzania, Zakład Nauk Podstawowych, ul. Czajkowskiego 109, 51-150 Wrocław, e-mail: amichaluk@wp.pl 
rów". Głównym problemem jest tu bowiem kwestia wizji, która jest zawsze warunkiem koniecznym do podjęcia racjonalnego działania. Jest ona bowiem coraz częściej związana z ponoszeniem coraz to większych nakładów (kosztów), a te, w przypadku porażki, mogą pogrążyć organizację i doprowadzić ją do porażki (bankructwa). Wśród wielu menedżerów zachodzi zatem obawa, czy są oni w stanie taką skończoną i spójną wizję działania organizacji zaproponować, godząc się równocześnie na poniesienie konsekwencji w przypadku porażki. Na szczęście to wyzwanie podejmują codziennie tysiące osób, które pragną wcielić w życie swoje pomysły, idee czy też, po prostu, zwykły biznes.

Problematyka przywództwa od wielu lat wydaje się niezwykle popularnym tematem wielu publikacji naukowych, nie tylko z zakresu nauk o zarządzaniu czy nauk społecznych, ale także różnego rodzaju poradników adresowanych nie tylko do współczesnych menedżerów. Wielu czytelników tych pozycji nie jest zainteresowana poznaniem stosunkowo złożonej istoty zjawiska przywództwa, a jedynie pragnie uzyskać poradę, jak zachować się (funkcjonować) w sytuacjach, kiedy zostanie im powierzona grupa osób w celu wykonania określonego zadania i zajdzie potrzeba sprawdzenia się $\mathrm{w}$ roli lidera.

Przywództwo w organizacji najczęściej jest utożsamiane z fascynacją osobą lidera, który mówi w sposób zrozumiały, stawia zadania ambitne, ale wykonalne, który potrafi dzielić się końcowym sukcesem, któremu można zaufać, którego - wreszcie - chce się naśladować. W tym stosunku do liderów jest swego rodzaju świadomość własnej niedoskonałości, ale też chęci przynależności do jakiejś społeczności, która odnosi sukcesy w swoim działaniu, także (głównie?) dzięki postawie i racjonalnemu zaangażowaniu lidera, a ostatnio, coraz częściej także dzięki grupom liderów. Jest też coś pierwotnego w tej chęci ,,podporządkowania” się przywódcy, który definiując, co chce osiągnąć, znalazł pewien sposób na to, jak to zrobić i... potrafił przekonać (zmotywować) do niego innych, w tym nas samych.

Problematyka przywództwa w organizacjach wojskowych wydaje się oczywista, a przykłady dowódców, którzy odnieśli sukces militarny dzięki skutecznemu przywództwu, są wykorzystywane powszechnie w edukacji nie tylko kandydatów na oficerów, ale także menedżerów, którzy mogą czerpać z tych wzorców skuteczne metody kierowania, a zwłaszcza motywowania podwładnych.

System wojskowy oparty na rozkazie jest szczególną formą kultury organizacyjnej. Jak podkreślał John Adair, wybitny specjalista z zakresu zarządzania, autor wielu poczytnych książek, to właśnie w akademii woj- 
skowej mógł najefektywniej zająć się problematyką przywództwa ${ }^{1}$. Podobnych związków z wojskiem deklaruje zresztą wielu innych specjalistów w tym zakresie

Transformacja Sił Zbrojnych RP to proces, który na początku XXI wieku dokonał znacznego przyśpieszenia, zwłaszcza poprzez rezygnację z zasadniczej służby wojskowej pełnionej z powszechnego poboru. Tej fundamentalnej dla obronności państwa zmianie, co ciekawe, wcale nie towarzyszyły szerokie dyskusje czy protesty zarówno po stronie wojskowych, których ta zmiana szczególnie dotyczyła, jak też społeczeństwa, które całą tę operację finansowało. Odbywała się ona bowiem w pewnym kontekście, który świadczył o wyczerpaniu się formuły armii opartej na powszechnej służbie wojskowej obywateli, zapoczątkowanej jeszcze przez rewolucję francuską. Proces zmian systemowych w polskiej armii był tu konsekwencją analogicznych reform dokonywanych w innych armiach NATO.

Od roku 2010 mamy zatem do czynienia z funkcjonowaniem w Polsce armii zawodowej, która swoją liczebnością i potencjałem militarnym stanowi fundament obronności państwa, a Siły Zbrojne RP realizują swoje zadanie konstytucyjne, czyli ochronę niepodległości państwa i niepodzielności jego terytorium oraz zapewnienie bezpieczeństwa i nienaruszalności jego granic ${ }^{2}$.

W tych nowych uwarunkowaniach organizacyjno-prawnych szczególnego znaczenia nabiera kształcenie nowoczesnych kadr oficerskich, które w każdej armii stanowią najistotniejszy element systemu dowodzenia. Przygotowaniem kadr oficerskich dla potrzeb polskiej armii zajmują się uczelnie wojskowe (szkoły oficerskie i akademie wojskowe).

W niniejszym artykule zaprezentowano elementy systemu kształcenia Wyższej Szkoły Oficerskiej Wojsk Lądowych im. generała Tadeusza Kościuszki we Wrocławiu, gdzie kształci się podchorążych dla podstawowego i największego komponentu Sił Zbrojnych RP, tj. Wojsk Lądowych ${ }^{3}$. Treścią artykułu jest prezentacja rozwiązań dot. projektowania i realizacji

1 John Adair pracował w latach 60. XX w. w Royal Military Academy Sandhurst w Wielkiej Brytanii jako wykładowca historii wojskowości, a równocześnie pełnił funkcję doradcy ds. szkolenia przywódców. Zob. także Adair, 2007.

2 Zob. art. 26 Konstytucji RP oraz art. 3 Ustawy z dnia 21 listopada 1967 r. o powszechnym obowiązku obrony Rzeczypospolitej Polskiej (DzU z 2012 r. poz. 461, 1101, 1407, 1445, z późn. zm.).

3 Kształceniem kandydatów na oficerów dla potrzeb Sił Zbrojnych RP zajmują się także: Wojskowa Akademia Techniczna w Warszawie, Akademia Marynarki Wojennej w Gdyni i Wyższa Szkoła Oficerska Sił Powietrznych w Dęblinie. 
treści kształcenia w zakresie przedmiotów zorientowanych na doskonalenie kompetencji przywódczych podchorążych, aby mogli oni skuteczniej dowodzić elementami struktury wojsk lądowych na pierwszym i kolejnych stanowiskach służbowych.

\section{DOBÓR KANDYDATÓW DO UCZELNI WOJSKOWEJ}

W aktualnych uwarunkowaniach prawnych, aby zostać powołanym do korpusu oficerów zawodowych Sił Zbrojnych RP, niezbędne jest ${ }^{4}$ :

- dla osób posiadających świadectwo maturalne - ukończenie studiów II stopnia w uczelni wojskowej w charakterze kandydata na żołnierza zawodowego,

- dla osób posiadających dyplom ukończenia studiów II stopnia ukończenie studium oficerskiego (szkolenia specjalistycznego) w wyższej szkole wojskowej w charakterze kandydata na żołnierza zawodowego;

- dla podoficerów zawodowych posiadających dyplom ukończenia studiów II stopnia - ukończenie studium oficerskiego (szkolenia specjalistycznego) w wyższej szkole wojskowej.

Procedura kwalifikowania kandydatów do korpusu oficerskiego jest stosunkowo złożona i wieloetapowa. Tak więc o przyjęcie do korpusu oficerskiego, poprzez odbycie właściwej służby kandydackiej, może ubiegać się osoba, która:

- posiada wyłącznie obywatelstwo polskie,

- posiada odpowiednią zdolność psychiczną i fizyczną do zawodowej służby wojskowej,

- posiada odpowiednie wykształcenie,

- nie był(a) karany(a) sądownie,

- ma co najmniej 18 lat,

- zda egzamin wstępny (test sprawności fizycznej i test znajomości języka obcego),

- odbędzie rozmowę kwalifikacyjną.

4 Zob. Ustawa z dnia 11 września 2003 r. o służbie wojskowej żołnierzy zawodowych (DU 2003 Nr 179 poz. 1750) zwana dalej „Ustawą”. 

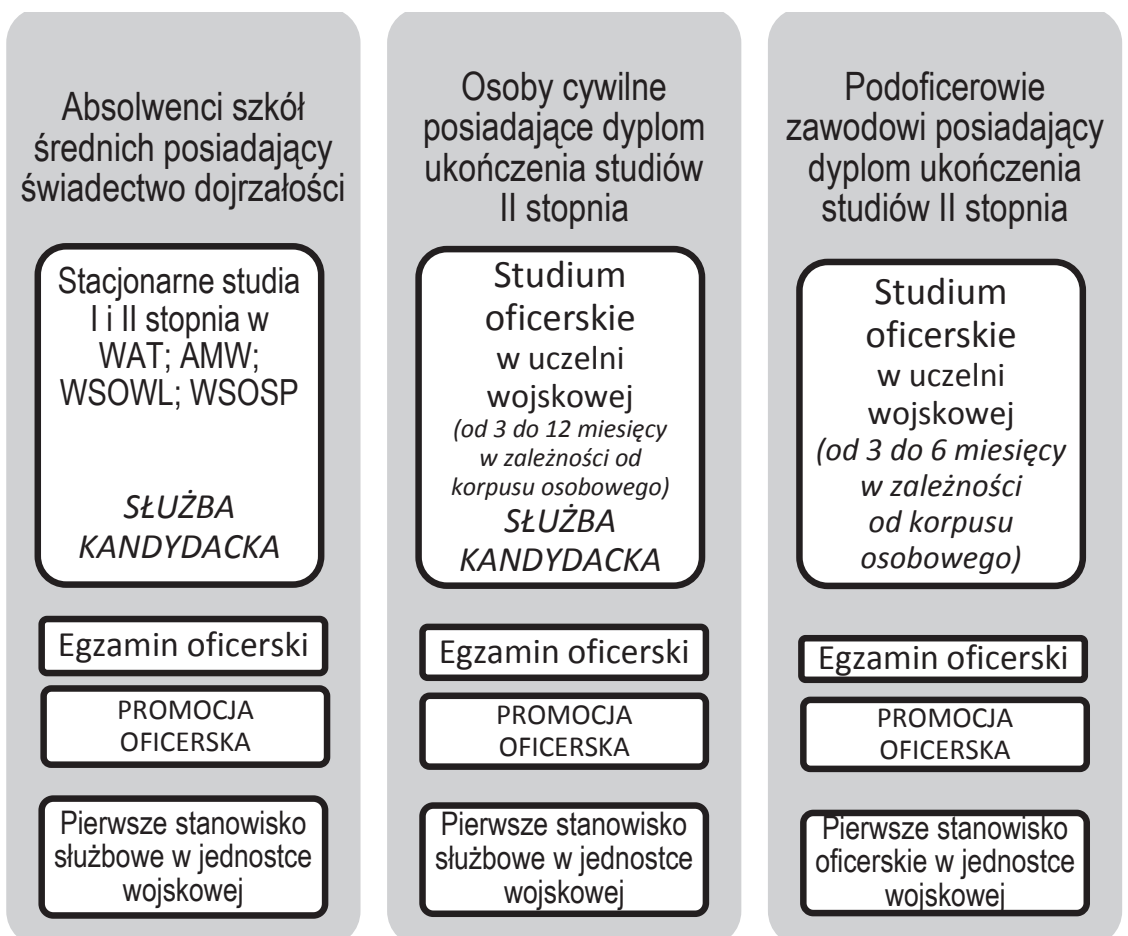

Rysunek 1. Modele kształcenia kandydatów na oficerów wg stanu na 2013 rok

Źródło: opracowanie własne na podstawie Ustawy z dnia 11 września 2003 o służbie wojskowej żołnierzy zawodowych (DzU 2003 Nr 179 poz. 1750, z późn. zm.)

Każdą osobę, która zgłosiła chęć pełnienia zawodowej służby wojskowej w korpusie oficerów zawodowych, właściwy wojskowy komendant uzupełnień kieruje w pierwszej kolejności do wojskowej komisji lekarskiej, celem ustalenia zdolności fizycznej i psychicznej do pełnienia zawodowej służby wojskowej, oraz do wojskowej pracowni psychologicznej w celu wydania orzeczenia psychologicznego. Należy tu podkreślić, że w orzeczeniach tych nie informuje się właściwych organów wojskowych o szczególnych predyspozycjach psychofizycznych kandydatów do korpusu oficerskiego, a jedynie o braku przeciwwskazań do pełnienia tej służby ${ }^{5}$. Orzeczenie psychologiczne wydaje uprawniony psycholog, a badania obejmują ocenę:

5 Zob. art. 5a Ustawy oraz Rozporządzenie Ministra Obrony Narodowej z dnia 31 sierpnia 2009 r. w sprawie badań psychologicznych osób zgłaszających chęć pełnienia zawodowej służby wojskowej (DzU 09.150.1214) 
- sprawności intelektualnej;

- cech osobowości;

- sprawności psychomotorycznej;

- poziomu dojrzałości emocjonalnej i społecznej.

Wszyscy zgłaszający się na studia w uczelni wojskowej, realizowane w charakterze kandydata na oficera, muszą przystąpić do egzaminu wstępnego składającego się z trzech odpowiednio punktowanych części:

- analiza wyników świadectwa maturalnego, polegająca na zsumowaniu punktów uzyskanych z dwóch przedmiotów maturalnych (wyłącznie wyniki części pisemnej wyrażone w skali punktowej) ${ }^{6}$ :

- test sprawności fizycznej (inny dla kobiet i inny dla mężczyzn);

- rozmowa kwalifikacyjna.

Rozmowy kwalifikacyjne prowadzą odpowiednie komisje złożone z doświadczonych oficerów i nauczycieli akademickich. Oceniają one predyspozycje kandydata do nauki w uczelni oraz predyspozycje do pełnienia zawodowej służby wojskowej w danym korpusie osobowym (grupie osobowej), jak również motywację do pełnienia zawodowej służby wojskowej.

Osoby, które pomyślnie przejdą procedurę kwalifikacyjną, zostają przyjęte na studia stacjonarne I stopnia pełnione w charakterze kandydata na żołnierza zawodowego (oficera). Wiąże się to także z podpisaniem kontraktu, który określa warunki studiów i konsekwencje, jakie winien ponieść kandydat, jeśli nie ukończy studiów i/lub nie podejmie służby na stanowisku oficerskim w jednostce wojskowej przez określony okres.

\section{KSZTAŁCENIE KANDYDATÓW NA OFICERÓW WOJSK LĄDOWYCH W WSOWL WE WROCŁAWIU}

Służba kandydacka w warunkach WSOWL to dla młodego mężczyzny czy (coraz częściej) kobiety rozpoczęcie całkiem nowego etapu w życiu i początek funkcjonowania w co najmniej kilku rolach [por. Kanarski, 1997]:

- roli żołnierza, jakim chcą go widzieć jego przełożeni - dowódcy wojskowi;

- roli studenta, jakim chcą go widzieć jego nauczyciele akademiccy;

6 Dla kandydatów na studia na kierunku Zarządzanie ocenia się wynik z matematyki (lub fizyki lub informatyki lub chemii) oraz języka angielskiego (na poziomie rozszerzonym lub podstawowym). 
- roli kolegi w grupie studenckiej (jakim chcą go widzieć inni podchorążowie z najbliższego otoczenia);

- roli dowódcy najniższego szczebla (drużyny, sekcji), jaką sprawuje podczas praktyk w jednostkach wojskowych czy podczas ćwiczeń poligonowych.

Wszystkie te wyzwania dla osób, które dopiero co zdały maturę i opuściły dom rodzinny, są niezwykle trudne i wielu podchorążych ma realne problemy w osiągnięciu pożądanej adaptacji do służby. Mamy tu bowiem do czynienia z koniecznością pogodzenia (poza realizacją programu studiów) wielu dodatkowych wymagań, jak choćby: „wojskowy” porządek dnia (pobudka, poranna zaprawa fizyczna, apele, stałe terminy posiłków itp.), zajęcia poligonowe, strzelania, treningi na placach ćwiczeń itp. Podchorążowie zakwaterowani $\mathrm{w}$ internatach mają także ograniczone możliwości opuszczania uczelni i inne rygory wynikające z trybu wojskowej stużby kandydackiej.

Specyfiką systemu edukacyjnego w uczelni wojskowej jest konieczność łączenia „cywilnych” treści kształcenia wymaganych na określonym kierunku studiów i specjalności (w przypadku WSOWL to kierunek $Z a$ rządzanie) z wiedzą i umiejętnościami specjalistyczno-wojskowymi wymaganymi na pierwszym stanowisku służbowym (tu: dowódcy plutonu) $\mathrm{w}$ jednostce wojskowej. Jest ona zorientowana na kształcenie w takich specjalnościach, jak: wojska zmechanizowane, aeromobilne, rozpoznanie wojskowe, artyleria, inżynieria wojskowa itp.

Studia dla kandydatów na oficerów dla potrzeb Wojsk Lądowych są realizowane w WSOWL w taki sposób, że wszyscy podchorążowie winni ukończyć studia I stopnia na kierunku Zarzadzanie, a studia II stopnia na kierunku Zarzadzanie lub na kierunku Bezpieczeństwo narodowe. Po zrealizowaniu programu kształcenia na studiach II stopnia, zdaniu egzaminu dyplomowego oraz odbyciu praktyki dowódczej podchorążowie przystępują do resortowego egzaminu oficerskiego, a po jego zaliczeniu są uroczyście promowani na pierwszy stopień oficerski podporucznika i są kierowanie na pierwsze stanowiska służbowe w jednostkach wojskowych.

System nauki we wrocławskiej uczelni wojskowej, podobnie jak w każdej szkole wyższej, obejmuje treści kształcenia: podstawowe, kierunkowe i specjalistyczne. Studia I stopnia trwają 8 semestrów i obejmują ogółem 4398 godzin oraz dodatkowe praktyki, jakie podchorążowie zaliczają w jednostkach wojskowych na stanowiskach dowódczych w podstawowych elementach struktury wojskowej. Strukturę programu przedstawia poniżej tabela 1. Różni się ona od tej, jaka jest realizowana w uczelniach cywilnych, 
tym, że mamy do czynienia z tzw. modułem wojskowym i wojskowym modułem specjalistycznym, które zawierają treści przyjęte w resorcie obrony narodowej jako niezbędne dla określonych grup specjalności wojskowych. W szczególności wyróżnia się tu znaczny wymiar godzin zajęć z Języka angielskiego (ogółem 660 godz. na studiach I stopnia i 156 godz. na studiach II stopnia). Jest to podyktowane koniecznością zdania egzaminu resortowego, zgodnego ze standardem STANAG obowiązującym w NATO. Zdanie tego egzaminu jest warunkiem koniecznym przystąpienia do egzaminu oficerskiego. Podobnie duży wymiar godzin zajęć to Wychowanie fizyczne, które na studiach I stopnia wynosi 436 godz. zajęć, a na studiach II stopnia 210 godz. Wysoki poziom sprawności fizycznej jest niezbędny zwłaszcza na pierwszych stanowiskach dowódczych w jednostkach wojskowych, a także jest weryfikowany w formie testu podczas egzaminu oficerskiego [zob. Regulamin, 2012].

Tabela 1. Struktura programu kształcenia kandydatów na żołnierzy zawodowych 8-semestrowe studia stacjonarne I stopnia na kierunku Zarządzanie obowiązująca od 2012 roku

\begin{tabular}{|l|c|}
\hline A. Moduł wojskowy & Godz. \\
\hline I. Grupa treści kształcenia podstawowego & 970 \\
\hline II. Grupa treści kształcenia kierunkowego & 657 \\
\hline B. Moduł kierunku studiów (zarządzanie) & \\
\hline I. Grupa treści podstawowych & 657 \\
\hline II. Grupa treści kierunkowych & 524 \\
\hline C. Moduł specjalistyczny (wojskowy) & 1554 \\
\hline D. Praca dyplomowa & 36 \\
\hline Razem & 4398 \\
\hline
\end{tabular}

Źródło: opracowanie własne za: Program I, 2012. 


\section{KSZTAŁCENIE KANDYDATÓW NA OFICERÓW W ZAKRESIE KOMPETENCJI PRZYWÓDCZYCH}

W przedstawionych uwarunkowaniach organizacyjno-programowych realizacja treści z zakresu nauk o zarządzaniu (menedżerskich) jest dość utrudniona, tym bardziej że moduł specjalistyczny jest poświęcony wyłącznie treściom wojskowym. Podstawowym zadaniem w projektowaniu programu było zatem dokonanie swoistej „superpozycji” treści „wojskowych" i „cywilnych”, by z jednej strony osiągnąc standardy dla kierunku Zarzadzanie, a z drugiej uzyskać kompetencje specjalistyczno-wojskowe niezbędne na konkretnych stanowiskach w wojskach lądowych.

W budowaniu treści programowych i projektowaniu kolejności ich realizacji w trakcie studiów jednym $\mathrm{z}$ wielu problemów do rozwiązania było opracowanie systemu kształtowania kompetencji przywódczych podchorążych. Z uwagi na brak możliwości diagnozowania tych zdolności u kandydatów starających się o studia, o czym wspomniano powyżej, wysiłek edukacyjny musi być zorientowany z jednej strony na prezentację niezbędnej wiedzy teoretycznej w zakresie szeroko rozumianego przywództwa, ale także zaprojektowanie szeregu zajęć praktycznych (ćwiczeń, treningów, seminariów), które umożliwiłyby doskonalenie stosownych umiejętności. W pracach projektowych chodziło także o to, aby skorelować wysiłki edukacyjne w tym zakresie podejmowane przez nauczycieli akademickich z tymi, jakie podejmują oficerowie-dowódcy będący opiekunami grup podchorążych w trakcie zajęć specjalistyczno-wojskowych na placach ćwiczeń, poligonach itp. Chodzi tu o wygenerowanie zjawiska synergii w kształtowaniu kompetencji przywódczych nie tylko w procesie dydaktycznym, ale także w różnych sytuacjach wynikających z toku służby kandydackiej w pododdziałach szkolnych. Działania te umożliwiają bowiem diagnozę zachowań i postaw przywódczych oraz ich korygowanie w trybie sprzężenia zwrotnego. Należy zaznaczyć, że ocena postaw i zachowań zgodnych $z$ charakterem służby oficerów zawodowych jest dodatkowym (ważnym) kryterium kwalifikowania kandydatów do zawodu oficera. Chodzi nie tylko o postawy przywódcze, które przecież nie zawsze uda się odpowiednio wykształcić, ale także o: dyscyplinę wojskową, gotowość do poświęceń, zachowania etyczne, honor, umiłowanie ojczyzny, szacunek dla przełożonych i starszych czy wreszcie wysokie morale (esprit de corps). 
W zakresie treści programowych wybrano przedmioty, które winny w szczególności służyć kształtowaniu kompetencji przywódczych podchorążych - przyszłych oficerów. Ich wykaz, zarówno na poziomie studiów I, jak i II stopnia, przedstawiono w tabeli 2 i 3 poniżej.

Tabela 2. Przedmioty kształtujące kompetencje przywódcze w programie studiów I stopnia dla kandydatów na żołnierzy zawodowych na kierunku Zarzqdzanie

\begin{tabular}{|l|c|}
\hline \multicolumn{1}{|c|}{ Nazwa przedmiotu } & Godz. \\
\hline 1. Działalność wychowawcza w wojsku & 54 \\
\hline 2. Podstawy dowodzenia & 16 \\
\hline 3. Działalność szkoleniowa w wojsku & 30 \\
\hline 4. Regulaminy Sił Zbrojnych RP & 46 \\
\hline 5. Podstawy zarządzania & 60 \\
\hline 6. Komunikacja społeczna & 20 \\
\hline 7. Przywództwo w dowodzeniu & 45 \\
\hline 8. Historia sztuki wojennej & 20 \\
\hline 9. Podstawy psychologii & 20 \\
\hline 10. Zachowania organizacyjne & 20 \\
\hline 11. Zarządzanie zasobami ludzkimi & 20 \\
\hline 12. Zarządzanie w sytuacjach zagrożeń & 20 \\
\hline $\begin{array}{l}\text { 13. Fakultet: } \\
\text { Trening potencjału kierowniczego } \\
\text { Warsztaty menedżerskie }\end{array}$ & 20 \\
\hline Razem & 391 \\
\hline
\end{tabular}

Źródło: opracowanie własne za: Program I, 2012. 
Tabela 3. Przedmioty kształtujące kompetencje przywódcze w programie studiów II stopnia dla kandydatów na żołnierzy zawodowych na kierunku Zarzadzanie

\begin{tabular}{|l|c|}
\hline \multicolumn{1}{|c|}{ Nazwa przedmiotu } & Godz. \\
\hline 1. Koncepcje zarządzania & 50 \\
\hline 2. Etyka w zarządzaniu & 30 \\
\hline 3. Negocjacje & 20 \\
\hline 4. Kapitał ludzki w organizacji & 30 \\
\hline 5. Psychologia w zarządzaniu & 30 \\
\hline $\begin{array}{l}\text { 6. Fakultet: } \\
\text { Trening potencjału kierowniczego } \\
\text { Trening technik motywacyjnych }\end{array}$ & 30 \\
\hline Razem & 190 \\
\hline
\end{tabular}

Źródło: opracowanie własne za: Program II, 2012.

Szczególne znaczenie w programie kształcenia przywiązuje się do przedmiotu Przywództwo w dowodzeniu, który jest realizowany w semestrze IV na studiach I stopnia. Stanowi on swego rodzaju podsumowanie treści z zakresu nauk o zarządzaniu. Treść przedmiotu Przywództwo $w$ dowodzeniu, który jest realizowany w formie 15 godz. wykładów i 30 godz. ćwiczeń, obejmuje następujące tematy:

1. Kierowanie - przewodzenie - dowodzenie. Ewolucja koncepcji kierowania. Postawy i zaangażowanie. Źródła władzy w organizacji. Kierownik - lider - dowódca. Style kierowania i ich stosowanie.

2. Dylematy przywództwa (kompetencje przywódcze). Teorie cech przywódczych. Kompetencje psychologiczne. Kompetencje prakseologiczne. Kompetencje społeczne. Manipulowanie i mobbing.

3. Systemy motywowania podwładnych. Przegląd teorii motywowania. Narzędzia przymusu administracyjnego. Narzędzia zachęty i perswazji. Procedury motywowania. Zasady doboru narzędzi motywowania.

4. Funkcjonowanie skutecznych zespołów. Grupa a zespół. Cechy pracy zespołowej. Cykl życia zespołu. Tworzenie zespołów - role zespołowe. Efektywność pracy zespołowej.

5. Komunikacja w zespołach. Bariery komunikacyjne. Stawianie zadań podwładnym. Konsultowanie zadań. Komunikowanie decyzji. Ocenianie podwładnych i korygowanie ich zachowań. 
6. Kultura organizacyjna a przywództwo. Istota i modele kultury organizacji. Uwarunkowania kultury organizacyjnej. Normy i wartości. Etyczne dylematy liderów. Savoir-vivre w zarządzaniu i dowodzeniu.

7. Zarządzanie zmianami - lider zmian. Pojęcie zmiany. Typy zmian $\mathrm{i}$ ich ocenianie. Opory wobec zmian. Wdrażanie zmian w organizacji. Liderzy zmian.

8. Gospodarowanie czasem. Błędy w zarządzaniu czasem i ich przyczyny. Indywidualny rytm aktywności. Zasada Eisenhowera. Zasada Pareto. Skuteczne planowania czasu.

\section{PODSUMOWANIE}

Celem niniejszego artykułu była prezentacja problematyki kształtowania kompetencji przywódczych w warunkach współczesnej wojskowej szkoły wyższej na przykładzie Wyższej Szkoły Oficerskiej Wojsk Lądowych we Wrocławiu. Ukazano w nim, jak złożone jest osiąganie celów szkoleniowych w tym zakresie i w jakim stopniu na końcowy efekt wpływają uwarunkowania będące konsekwencją istniejącego modelu szkolnictwa wojskowego. Wskazano także na kwestię niedostatecznych procedur doboru kadr do służby kandydackiej w WSOWL, gdzie mimo wielu kandydatów nie diagnozuje się kompetencji przywódczych, tak ważnych w trakcie służby wojskowej w uczelni, ale także na pierwszym i kolejnych stanowiskach służbowych. Z uwagi na ograniczony wymiar artykułu autor skupił się głównie na prezentacji uwarunkowań, jakie mają miejsce w prezentowanej uczelni, kształcącej największą liczbę oficerów dla Wojsk Lądowych, skupiając się na wybranych przedmiotach kształcenia, zawierających treści z zakresu doskonalenia kompetencji przywódczych.

W uczelni mamy bowiem świadomość, że jej absolwenci zetkną się $\mathrm{w}$ jednostkach wojskowych $\mathrm{z}$ doświadczoną kadrą podoficerską oraz żołnierzami korpusu szeregowych zawodowych, z których wielu będzie miało wieloletnie doświadczenie zawodowe i umiejętności zdobyte w trakcie misji wojskowych w Iraku i w Afganistanie. Dowodzenie takimi zespołami to spore wyzwanie dla młodych dowódców, a także świadomość odpowiedzialności uczelni w ich właściwym przygotowaniu do tej roli. 


\title{
LITERATURA
}

Adair J., (2007), Rozwijanie umiejętności przywódczych, Wyd. ABC a Wolters Kluwer business, Kraków.

Kanarski L., (1997), Negatywne zjawiska w stużbie wojskowej i metody ich ograniczania, [w:] Dyrda M. J. (red.), Psychologia w wojsku, Dep. Społeczno-Wychowawczy MON, Warszawa.

Program I, (2012), Program kształcenia dla kandydatów na żolnierzy zawodowych Studia I stopnia Kierunek studiów: Zarzadzanie, WSOWL, Wrocław.

Program II, (2012), Program ksztatcenia dla kandydatów na żolnierzy zawodowych Studia II stopnia Kierunek studiów: Zarzadzanie, WSOWL, Wrocław.

Regulamin, (2012), http://www.wso.wroc.pl/images/pliki/statut_wsowl/regulamin_studiow_wsowl.pdf (22.11.2013)

\section{THE LAND FORCES OFFICER-CADETS EDUCATION FOR THE LEADERSHIP COMPETENCIES}

\begin{abstract}
A b stract: Article presents the results of research, made in the Faculty of Management of General Tadeusz Kosciuszko Military Academy of Land Forces, in design of the officer-cadets curriculum structure. The study was focused primarily on the managing (command, leadership) competence during the study and evaluation of its suitability for the first and subsequent officer positions (officers) in military units.

K e y w o r d s: leadership; curriculum structure; military education; officer-cadets education.
\end{abstract}

